\title{
PENINGKATAN KAPASITAS PENGAJAR BAHASA INGGRIS SECARA DARING (ONLINE) DALAM PANDEMI COVID-19
}

\author{
Helena Magdalena Rijoly, S.Pd., M.Pd. ${ }^{1}$, Simon Josef Matakupan, S.Pd., M.A. ${ }^{2}$ \\ ${ }^{1}$ Program Studi Pendidikan Bahasa Inggris, FKIP, Unpatti, rijolyhelenadell@gmail.com \\ ${ }^{2}$ LKP LEAP Language Study Center Ambon, smatakupan@gmail.com
}

\begin{abstract}
Abstrak: Dalam situasi pandemic Covid-19, semua level Pendidikan dari PAUD hingga Universitas diminta untuk menerapkan perkuliahan daring (online) sebagai salah satu Langkah pencegahan penyebaran virus Covid-19 tersebut. Tidak ketinggalan, sektor Pendidikan luar sekolah seperti tempattempat kursus dan bimbel juga perlu untuk beradaptasi dengan menyesuaikan moda pembelajaran mereka ke moda daring (online). LKP LEAP Language Study Center adalah salah satu tempat kursus Bahasa Inggris di Ambon yang segera berbenah untuk penyesuaian ini. Salah salah satunya adalah dengan program peningkatan kapasitas pengajar yang akan melayani program kelas daring (online). Program peningkatan kapasitas pengajar ini dilakukan lewat pelatihan dan pendampingan online yang berlangsung dari bulan Mei hingga bulan Juni 2020. Hasil dari program ini adalah 16 pengajar yang siap dari segi ketrampilan dan pengetahuan untuk mengelola pembelajaran daring (online) serta sistem pengelolaan pembelajaran daring (Online Learning Management System) yang siap diterapkan. Artikel ini memaparkan proses persiapan dan hal-hal yang perlu dipersiapkan dalam hal pengelolaan pembelajaran daring (online).
\end{abstract}

Kata Kunci: Pembelajaran Bahasa Inggris, Pembelajaran daring (online), Pelatihan Tenaga pengajar, Learning Management System

AbstractIn a Covid-19 pandemic, all education institutes from Early Education Centre to University were asked to conduct an online learning as one of the efforts to prevent the spread of Covid-19 virus. Informal education sector such as Language Courses and Learning Tutorial Institutes are also forced to adapt by adjusting the teaching and learning modes from face-to-face class meeting to online class meeting. LKP LEAP Language Study Centre is one of the English Language Course in Ambon who strives to adapt to these changes. One of the steps for this is to conduct a teachers' capacity building program for teachers who will serve its online class program. This teacher's capacity building program was conducted from May to June 2020. The results of the program are: 1) the 16 teachers are ready in the aspect of skills and knowledge to manage an online learning, 2) A ready to use Online Learning management system and all the supporting system. This article discusses the process of training to the establishment and the opening of Online learning at LEAP Ambon.

Keywords: English Teaching, Online Learning and Teaching, Teachers' Training, Learning Management System.

\section{PENDAHULUAN}

Awal tahun 2020 dimulai dengan penyebaran Novel Virus Covid-19 ke seluruh dunia dengan kecepatan yang cukup mengkhawatirkan. Pada bulan Maret 2020, ditemukan kasus pertama penularan Covid-19 di Indonesia. Hal ini menyebabkan banyak kebijakan darurat yang diambil demi menghentikan penyebaran virus ini.

Keputusan presiden nomor 7 tahun 2020 tanggal 13 maret tentang gugus tugas penanganan corona virus disease menetapkan bahwa kegiatan dengan mengumpulkan masa dengan jumlah yang banyak tidak dapat dilaksanakan. Hal ini termasuk juga dengan penyelenggaraan pendidikan. Kementerian Pendidikan dan Kebudayaan meresponi hal ini dengan mengeluarkan Surat Edaran No. 35492/A.A5/HK/2020 yang mengatur pencegaran penyebaran Covid-19 di lingkungan Kementerian Pendidikan dan Kebudayaan. Dengan demikian semua aktivitas akademik di semua level pendidikan, dari PAUD hingga Perguruan Tinggi dan Pendidikan 
Luar sekolah di Indonesia dihimbau untuk dihentikan dan diganti dengan pelaksanaan bekerja dan belajar dari rumah lewat daring (online).

Kondisi dimana sektor pendidikan secara tiba-tiba harus berpindah ke model pembelajaran online membawa banyak tantangan baik dari segi fasilitas dan infrastruktur maupun dari segi kesiapan ketrampilan dan pengetahuan digital dari guru, siswa maupun orang tua. Institusi pendidikab baik formal dan informal didorong untuk secara kreatif mengadaptasikan teknologi dalam proses pembelajarannya. Sekerteariat Kabinet Republik Indonesia (Setkab, 2020) melaporkan bahwa terdapat peningkatan tajam dalam penggunaan video conferenceing, learning management system (LMS) dan strategi komunikasi jarak jauh lainnya yang digunakan oleh institusi pendidikan dalam situasi darurat ini. Namun tentu saja pengalihan mendadak ini juga memperlihatkan tantangan besar yang harus dihadapi oleh para pengajar. Fauzi dan Kuzuma (2020) melakukan survey kepada para guru mengenai kondisi pembalajaran daring dalam masa pandemi Covid-19. Survey menemukan 4 tantangan terbesar yaitu

a. Ketersediaan fasilitas dan infrastruktus yang mampu menunjang pembelajaran daring seperti perangkat eletronik (HP, laptop, komputer, listrik)

b. Ketersediaan dan akses internet,

c. Kesiapan pengetahuan dan ketrampilan untuk merencanakan, mengimplementasikan dan mengevaluasi pembelajaran.

d. Belum sinerginya kolaborasi dengan orang tua

Hambatan dan tantangan yang disebutkan diatas didukung pula oleh penelitian Purwanto et.al (2020) yang menyebutkan beberapa kesulitan terbesar seperti pemahaman dan ketrampilan guru dan orang tua dalam menggunakan teknologi dalam pembelajaran online yang terbatas, tingginya biaya koneksi internet dan tambahan beban waktu dan tanggung jawab bagi orang tua untuk mendampingi anak belajar. Dampak ekonomi dari pembelajaran daring ini juga semakin terasa ketika orang tua kesulitan dalam mencari nafkah sementara tuntutan pendidikan mengisyaratkan kebutuhan finansial yang tidak kecil (Azzahra, 2020). Situasi dan kondisi ini juga terjadi di Maluku (Siwalimanews, 2020) dan terkhusus untuk Maluku faktorfaktor yang disebutkan diatas sangat nyata terjadi dan dirasakan.

LKP LEAP Language Study Center atau LEAP Ambon adalah salah satu tempat kursus dan pelatihan bahasa inggris di Ambon. Ketika pandemi melanda, aktivitas kelas-kelas kursus juga terhenti. Setelah 2 bulan berlalu, permintaan atas pembelajaran alternatif semakin banyak diutarakan oleh para orang tua dan siswanya. Namun LEAP Ambon menyadari bahwa memulai kelas online bukanlah hal yang dapat dianggap enteng. Program kelas online bukan sekedar membuat Learning Management System (LMS) seperti Google Classroom atau Menggunakan Zoom meeting untuk virtual class saja. Sebagai sebuah wadah pelatihan dan kursus, LEAP Ambon perlu mengatur dan memperhatikan pencapaian pembelajaran sesuai dengan kurikulum serta memastikan bahwa proses ini dapat berjalan dengan efektif dan efisien (Huang, Spector, \& Yang, 2019; Jonson, 2014).

LEAP Ambon adalah kursus Bahasa Inggris bagi jenjang TK-B sampai SMA/Universitas ditambah dengan beberapa program lain seperti persiapan TOEF/IELTS dan conversation classes. Untuk memastikan bahwa program online dapat berjalan dengan baik, ada beberapa hal utama yang diperhatikan oleh LEAP Ambon (Huang, Spector, \& Yang, 2019):

- Kesiapan dan kompetensi pengajar dalam menggunakan platform teknologi dalam menjalankan proses belajar mengajar.

- Kesiapan dan kompetensi pengajar dalam menyesuaikan aktivitas pembelajaran online dengan capaian pembelajaran kurikulum yang dibuat untuk pembelajaran tatap muka

- Kesiapan siswa dan orang tua dalam mengikuti program kelas online.

LEAP Ambon kemudian mengambil 2 langkah utama dalam mempersiapkan program kursus online yaitu: Workshop online Peningkatan Kapasitas Pengajar dan Pengembangan Paket Pelatihan Bagi Siswa dan Orang Tua. 
Pelaksanaan Workshop online dan Pengembangan paket pelatihan ini adalah program persiapan pembukaan Kursus Online LEAP Ambon. Program ini dilakukan dengan bekerja sama dengan salah satu dosen Program Studi Pendidikan Bahasa Inggris - FKIP Unpatti yang adalah salah satu pendiri LEAP Ambon. Dalam program persiapan pembukaan kursus online LEAP Ambon ini beliau bertindak sebagai konsultan dan trainer.

\section{METODE}

Program persiapan pembukaan kursus online LEAP Ambon ditargetkan pada 2 kelompok sasaran. Persiapan bagi Pengajar LEAP Ambon dan Persiapan bagi siswa dan orang tua. Persiapan bagi pengajar LEAP Ambon menggunaan metode pelatihan dalam format Workshop Online. Sedangkan Persiapan bagi siswa dan orang tua menggunakan metode penyuluhan online lewat paket video tutorial dan sesi try-out dan tanya jawab virtual.

\section{a. Workshop Online Peningkatan Kapasitas Pengajar LEAP Ambon}

Pelaksanaan workshop online terbagi atas 3 tahapan: 1) adaptasi kurikulum, pemilihan platform dan penetapan sistem, 2) Pelatihan 3) pendampingan.

\section{- Tahap Adaptasi Kurikulum, Pemilihan Platform dan Penetapan Sistem}

Tahap ini dilakukan dalam bulan Mei 2020 selama 2 minggu. Konsultan/Trainer bekerja sama dengan pimpinan LEAP Ambon meninjau kurikulum bagi semua level dan membuat alternatif aktivitas pembelajaran yang disesuaikan dengan kemampuan siswa, jenjang belajar dan keterbatasan/kelebihan proses belajar online.

Pada saat yang bersamaan, tahap ini juga menyesuaikan dengan platform online yang akan digunakan. Beberapa try-out dilakukan dengan berkaca dari pengalaman mengajar online yang telah dilakukan selama ini.

Tahap ini juga mengembangkan sistem informasi dan komunikasi antara LEAP Ambon dengan pengajar, Pengajar dengan siswa, LEAP Ambon dengan orang tua dst. Hal ini sangat penting demi melancarkan proses pembukaan dan pelaksanaan program kelas kursus online.

Hal yang paling penting dilakukan dalam tahap ini adalah juga melakukan survey atas kesiapan (Kemampuan menggunakan teknologi) dan ketersediaan fasilitas/infrastruktur yang dimiliki oleh pengajar, siswa dan orang tua (Huang, Spector, \& Yang, 2019). Survey ini dilakukan secara online dengan menggunakan platform Google Form.

- Tahap Pelatihan

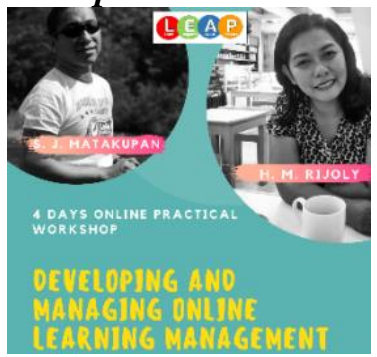

Gambar 1 Flyers Workshop Online LEAP Ambon

Pelatihan dilakukan dalam format workshop online yang pada awalnya direncanakan untuk berjalan selama 4 hari, namun pada prakteknya berjalan selama 1 minggu. Workshop online ini diberi nama "Developing and Managing Online Learning Management System" atau Pengemangan dan Pengelolaan Sistem Manajemen Pembelajaran Online. Peserta workshop online ini adalah 16 pengajar tetap LEAP Ambon.

Workshop online ini dilaksanakan dengan menggunakan 2 platform yaitu: Google Classroom, Zoom Meeting. Ada 4 pokok materi yang dibawakan dalam workshop ini yaitu: 1) Pengenalan pada cara mengembangkan LMS, 2) Memadukan penggunaan aplikasi dan program penilaian/test online dengan LMS, 3) Perencanaan dan Pengembangan Pokok isi materi pengajaran online - Lesson Planning, dan 4) Pengembangan perangkat mengajar dan aktivitas untuk pembelajaran online. 
Workshop ini adalah pelatihan aktif dan interaktif sehingga masing-masing peserta bertanggung jawab atas 1 level kelas yang diampuhnya. Selama pelatihan, peserta langsung melakukan penerapan kepada level kelas-nya. Pada akhir pelatihan 16 level yang ada pada LEAP Ambon telah mempunyai perangkat, materi, aktivitas serta platform LMS yang siap digunakan.

- Tahap Pendampingan

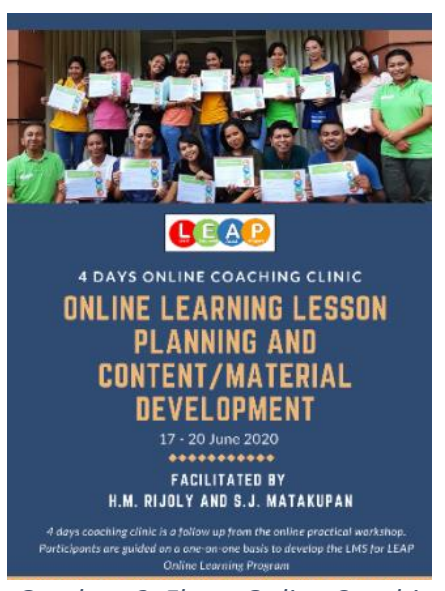

Gambar 2 Flyers Online Coaching Clinic LEAP Ambon

Setelah 2 tahap ini dilalui, program kursus online tidak langsung dibuka. Hal ini akan menjadi terlalu premature. Sistem, LMS dan Kesiapan pengajar perlu diuji dulu agar pada saatnya mereka benar-benar siap. Perlu kita ingat bahwa pengalaman belajar dan mengajar secara online adalah sesuatu yang benar-benar asing sebelum adanya pandemic Covid-19 (Fauzi \& Khusuma, 2020). Untuk itu tahapan pendampinganpun dilaksanakan dengan kegiatan yang dinamakan coaching clinic.

Coaching Clinic ini dilakukan secara online dengan menggunakan platform Google Classroom dan Zoom dan diikuti oleh 16 pengajar tetap. Pada awalnya direncanakan untuk berjalan selama 4 hari namun pada prakteknya coaching clinic ini berlangsung selama 1 minggu.

Dalam tahap ini, para pengajar melakukan peer teaching dengan pengajar menjadi student di kelas pengajar yang lain untuk menguji coba proses pembelajaran. Pada saat yang bersamaan, pengajar juga melakukan pendampingan intensif dengan konsultan/trainer untuk merevisi dan menyesuaikan lesson plan, materi, aktivitas, pola penilaian dll (Jonson, 2014). Hal ini berkaitan erat dengan proses persiapan paket pelatihan bagi siswa dan orang tua.

\section{b. Paket Pelatihan Bagi Siswa dan Orang Tua}

Memiliki sistem dan LMS platform yang siap belumlah cukup untuk memastikan terselenggaranya proses belajar mengajar. Pengguna atau siswa LEAP Ambon adalah elemen terpenting. Untuk kasus LEAP Ambon, perlu juga untuk melibatkan orang tua karena untuk kelas-kelas anak kecil, orang tua berperan sangat besar dalam memastikan terjadinya pembelarajan (Huang, Spector, \& Yang, 2019). Untuk paket pelatihan ini tidak hanya dibuat bagi siswa namun juga bagi orang tua.

Paket pelatihan ini terdiri dari serangkaian video tutorial yang meliputi semua aspek bagaimana menggunakan platform online LEAP Ambon seperti Googel Classroom, Zoom Meeting, Quizizz, Kahoot, Padlet dan banyak lagi. Video tutorial ini dibuat bersama dengan para pengajar.

Paket Pelatihan penggunaan platform dan aplikasi bagi siswa dan orang tua terselesaikan pada akhir bulan Juni 2020.

Selain daripada itu, dilakukan juga survey dan diskusi langsung untuk mendapatkan baseline data dari pengajar dan siswa/orang tua. Baseline data sangat penting sebagai data empiris yang menentukan strategi/Teknik peengajaran dan keputusan pemilihan platform untuk pelaksanaan program kursus online.

\section{HASIL DAN PEMBAHASAN}

Beberapa informasi berhasil dikumpulkan dari survey cepat (Google Form) pada siswa dan pengajar. Baseline Informasi ini terbagi atas beberapa bagian:

- $\quad$ Kesiapan Pengajar 
Data kesiapan pengajar didapatkan lewat diskusi langsung dalam rapat bulanan LEAP Ambon pada bulan Mei 2020. Hasil diskusi menunjukan bahwa 16 pengajar yang dimiliki pengetahuan dan ketrampilan yang cukup dalam hal pengenalan akan platform yang akan digunakan maupun dengan ketrampilan memadukan platform dan program/aplikasi online untuk tujuan pengajaran.

Dari segi kesiapan mengajar, 16 pengajar LEAP Ambon telah sangat memahami kurikulum dan konsep mengajar yang di terapkan di LEAP Ambon. Mereka juga siap untuk mempelajari teknis dan strategi belajar baru yang digunakan dalam Kursus Online.

Para pengajar ini telah berpengalaman mengajar 6 tahun, 3 tahun dan 2 tahun bersama dengan LEAP Ambon. Maka untuk aspek ini, tidak terindikasi masalah yang berarti. Hal ini dibuktikan bahwa dalam 1 bulan pelatihan dan pendampingan, semua pengajar mampu bekerja dengan efektif dan efisien serta menghasilkan lesson plan, materi, aktivitas mengajar dan sistem pengeleloaan pengajaran online yang terpadu sesuai dengan jenjang/level kelas yang mereka pegang di LEAP Ambon.

\section{- $\quad$ Kesiapan Siswa dan/atau Orang tua}

Data untuk aspek ini didapatkan lewat survey online dengan menggunakan google form. Ada 212 responden yang mengembalikan survey dary 254 siswa yang terdaftar pada LEAP Ambon. Beberapa pertanyaan dalam survey tersebut menanyakan kesiapan anak dan orang tua dalam hal pengetahuan dan kemampuan mereka dalam memggunakan platform dan program/aplikasi online yang akan digunakan dalam proses kursus online.

Hasil survey menunjukan bahwa anak dan orang tua sangat mahir menggunakan WhatsApp dan YouTube. Orang tua cukup banyak yang paham menggunakan Zoom meeting. Hal ini dikarenakan mereka telah menggunakannya untuk urusan pekerjaan kantor selama masa pandemi. Sementara Anak terindikasi belum familiar.

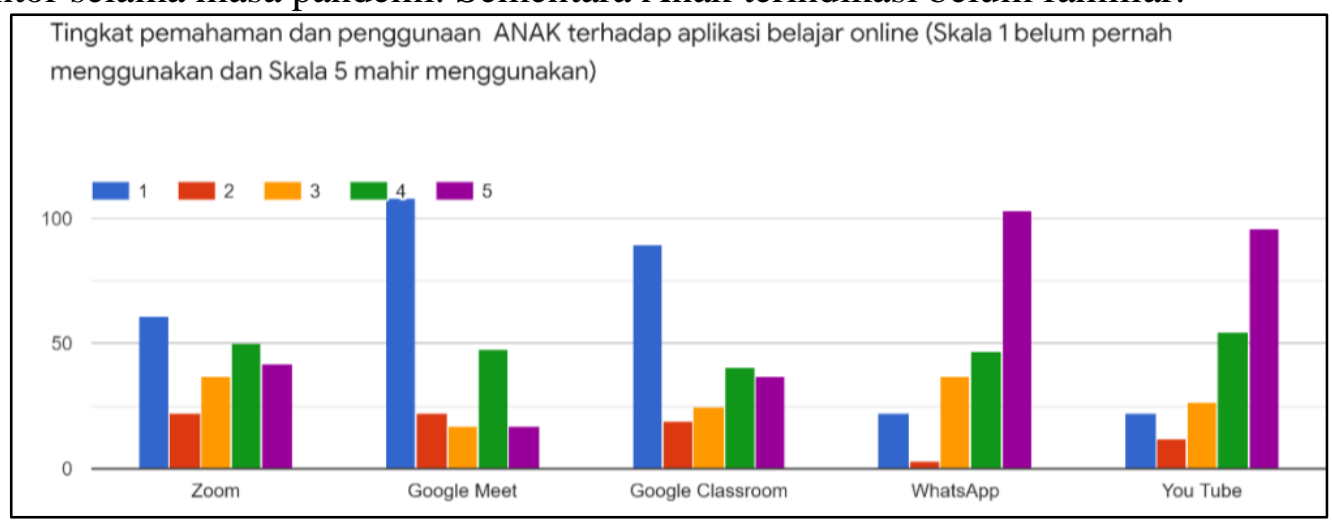

Gambar 3 Grafik tingkat pemahaman dan penggunaan anak

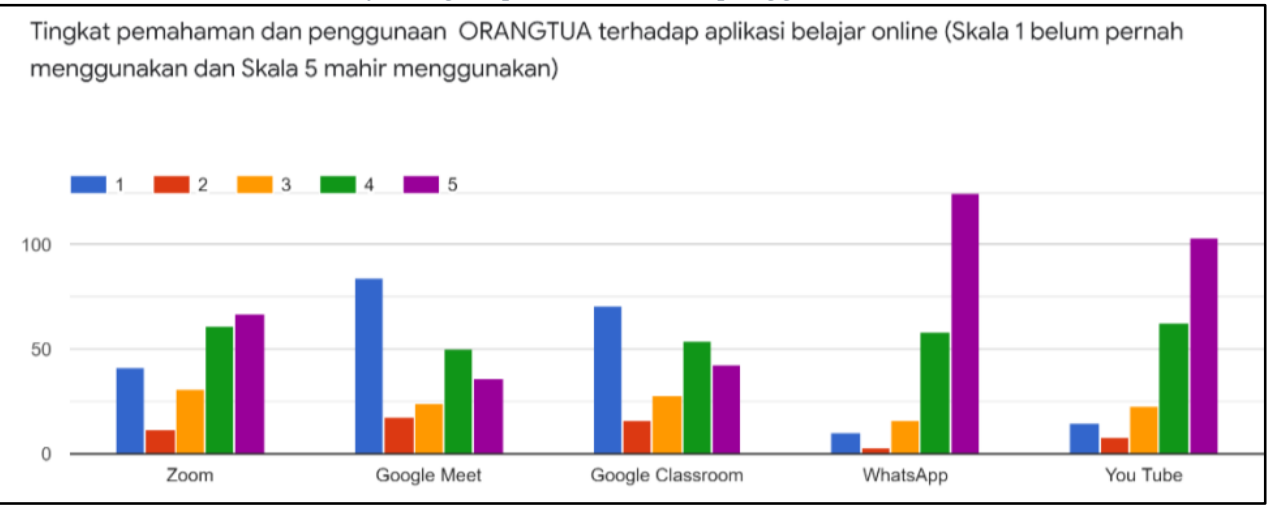

Gambar 4 Grafik tingkat pemahaman dan penggunaan Orang Tua 
- $\quad$ Ketersedian Perangkat Elektronik untuk menunjang Proses Pembelajaran

Data untuk aspek ini didapatkan lewat survey online dengan menggunakan google form. Beberapa pertanyaan dalam survey tersebut menanyakan secara spesifik ketersediaan perangkat elektronik yang akan digunakan dalam proses kursus online dan kemampuan penggunaannya.

Hasil survey menunjukan bahwa $99.1 \%$ siswa memiliki HP dirumah dan $84 \%$ memiliki Komputer/laptop dirumah. Dengan demikian dari sisi fasilitas yang dapat digunakan untuk menunjang pembelajaran online, para siswa tidak akan menemui masalah.

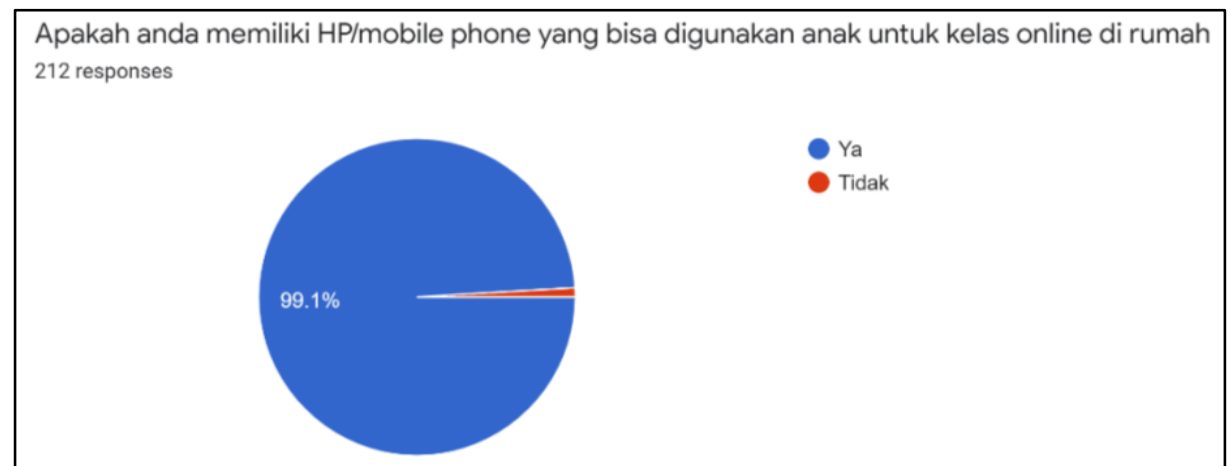

Gambar 5 Ketersediaan HP

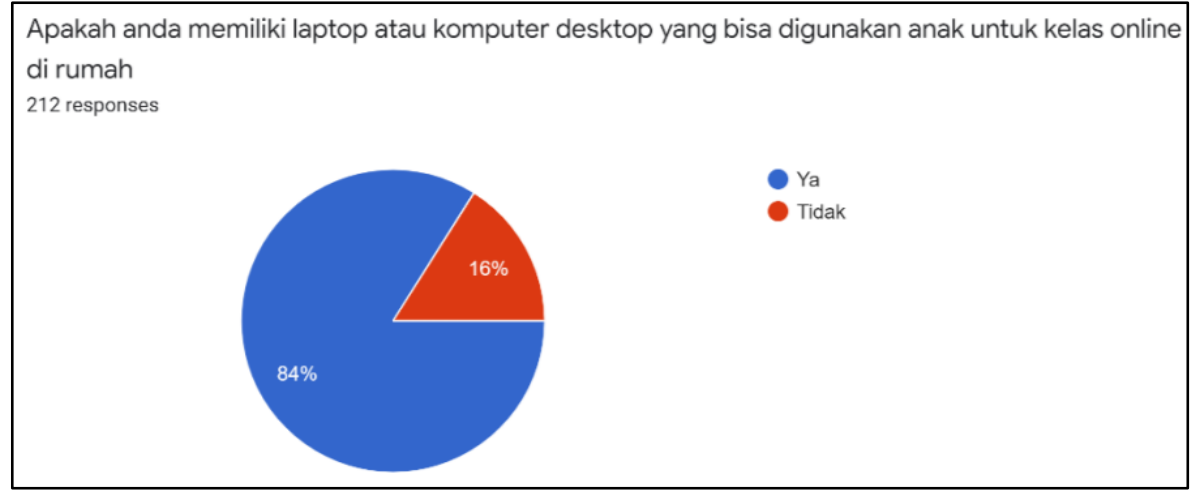

Gambar 6 Ketersediaan Komputer

- $\quad$ Kemampuan untuk mengakses internet

Data untuk aspek ini didapatkan lewat survey online dengan menggunakan google form. Beberapa pertanyaan dalam survey tersebut menanyakan ketersedian akses internet yang akan digunakan dalam proses kursus online.

Hasil survey menunjukan bahwa semua siswa memiliki akses internet dengan koneksi dan kekuatan jaringan yang baik. 3.8\% tidak memiliki koneksi internet langsung dirumah namun menyatakan bahwa mereka dapat mengakses internet dengan bergabung dengan tetangga atau mendapatkan internet dari kantor dll. Namun data dibawah ini terdapat overlap data, karena pertanyaan survey menanyakan akses yang dimiliki. Hingga satu responden bisa memilih lebih dari 1 jenis akes. 


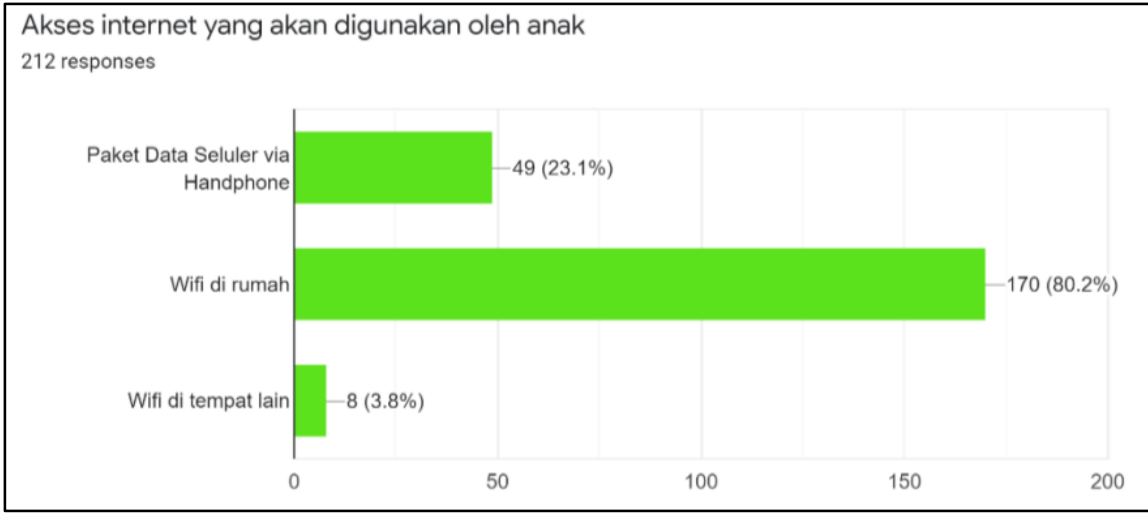

Gambar 7 Akses pada internet

Berdasarkan baseline data ini, dapat dilihat bahwa program kursus online sangat dapat dijalankan dengan situasi dan kondisi siswa dan orang tua dari LEAP Ambon. Kekurangan dalam kesiapan/kemampuan siswa dan orang tua untuk mengikuti proses pembelajaran online dapat disiasati dan diselesaikan dengan mengirimkan paket pelatihan dan sesi tutorial.

\section{KESIMPULAN}

Keputusan untuk memulai dan membuka kursus online bukan sebuah keputusan yang diambil secara mendadak dan dijalankan secepat mungkin. Ketika kelas online adalah untuk sebuah institusi maka ada banyak pertimbangan dan persiapan yang harus dilakukan. Hal yang paling penting untuk dilakukan selain pelatihan pengajar dan penyesuaian kurikulum mengajar adalah baseline survey yang dilakukan kepada pengguna layanan institusi tersebut. Informasi dari baseline survey akan menuntun pemilihan dan keputusan yang dibuat dalam sistem dan pengelolaan pembelajaran online. -

\section{REFERENCES}

Azzahra, N. F. (2020, May 8). [Policy Brief] Addressing Distance Learning Barriers in Indonesia Amid the Covid-19 Pandemic. Retrieved from Center for Indonesian Policy Studies: https://www.cips-indonesia.org/post/addressing-distance-learning-barriers-inindonesia-amidthe-covid-19-pandemic

Fauzi, I., \& Khusuma, I. S. (2020, June). Teachers' Elementary School in Online Learning of COVID-19 Pandemic Conditions. Jurnal Iqra': Kajian Ilmu Pendidikan, 5(1), 58 - 70. doi:https://doi.org/10.25217/ji.v5i1.91

Guri-Rosenbli, S. (2018). E-Teaching in Higher Education: An Essential Prerequisite for E-Learning. Journal of New Approaches in Educational Research, 7(2), 93-97. doi:https://doi.org/10.7821/naer.2018.7.298

Huang, R., Spector, J. M., \& Yang, J. (2019). Educational Technology: A Primer for the 21 st Century. Singapore: Springer.

Jisc. (2019, April 12). Preparing for Education 4.0. Retrieved from THE - Times High Education: https://www.timeshighereducation.com/hub/jisc/p/preparing-education-40\#survey-answer

Jonson, J. (2014, January 20). Blended Learning and Technology Integration. Retrieved September 21, 2019, from YouTube-JenJonson: https://www.youtube.com/watch?v=KD8AUfGsCKg

Karnad, A. (2014). Trends in Educational Tehnologies. London, UK: LSE EPrints.

Kentnor, H. (2015, January 10). Distance Education and the Evolution of Online Learning in the United States. Curriculum and Teaching Dialogue, 17(1), pp. 21 - 31.

Prensky, M. (2001). Digital Natives, Digital Immigrants. On the Horizon, 9(5), 1 - 6. Retrieved June 2020

Setkab. (2020, Mei 2). COVID-19 Pandemic Brings Fresh Ideas in Learning Methods: President Jokowi. Retrieved June 2020, from Cabinet Secretary of The Republic of Indonesia: https://setkab.go.id/en/covid-19-pandemic-brings-fresh-ideas-in-learning-methods-presidentjokowi/ 
Siwalimanews. (2020, Maret 19). ASN \& Sekolah Libur: Cegah Penyebaran Virus Corona. Retrieved from Siwalima News.Com: https://siwalimanews.com/asn-sekolah-libur/ 